\title{
FAILURE OF BILATERAL DIPLOMACY ON IRIAN BARAT (PAPUA) DISPUTE (I950-I954)
}

\author{
Siswanto \\ Center for Political Studies, \\ The Indonesian Institute of Sciences, Jakarta \\ E-mail:sish_jakarta@yahoo.com
}

\begin{abstract}
Fundamentally, Irian Barat (Papua) dispute between The Netherlands -Indonesia was a territorial conflict or an overlapping claim. The Netherlands as the former colonialist did not want to leave Irian Barat (Papua) or remained still in the region, meanwhile Indonesia as the former colony denied the Netherlands status quo policy in Irian Barat (Papua). Potential dispute of the Irian Barat (Papua) was begun in the Round Table Conference (RTC) 1949. There was a point of agreement in RTC which regulates status quo on Irian Barat (Papua) and it was approved by Head of Indonesia Delegation, Mohammad Hatta and Van Maarseven, Head of the Netherlands Delegation. As a mandate of the RTC in I950s there was a diplomacy on Irian Barat (Papua) in Jakarta and Den Haag. Upon the diplomacy, there were two negotiations held by diplomats of both countries, yet it never reached a result. As a consequence, in I954 Indonesia Government decided to stop the negotiation and searched for other ways as a solution for the dispute. At the present time, Jakarta-Papua relationship is relatively better and it is based on a special autonomy, which gives great authority to the Local Government of Papua.
\end{abstract}

Keywords: the Netherlands, Indonesia, status quo, Irian Barat (Papua), diplomacy

\begin{abstract}
Abstrak
Pada dasarnya perselisihan Irian Barat (Papua) antara Belanda -Indonesia adalah konflik teritorial atau tumpang tindih klaim. Belanda sebagai mantan penjajah tidak ingin meninggalkan Irian Barat (Papua) atau masih ingin menduduki kawasan itu, di sisi lain Indonesia sebagai bekas bangsa terjajah menolak kebijakan status quo Belanda di Irian Barat (Papua). Potensi perselisihan Irian Barat (Papua) dimulai pada Konferensi Meja Bundar (RTC) I949. Ada kesepakatan dalam RTC yang mengatur status quo di Irian Barat (Papua) dan itu disetujui oleh Kepala Delegasi Indonesia, Mohammad Hatta dan dan Van Maarseven, Kepala Delegasi Belanda. Sebagai mandat RTC pada I950-an ada diplomasi untuk Irian Barat (Papua) di Jakarta dan Den Haag. Negosiasi dua kali dilakukan oleh diplomat kedua negara, tetapi tidak pernah mendapatkan hasil sama sekali. Akhirnya pada tahun I954 keputusan Pemerintah Indonesia menghentikan negosiasi dan mencari cara lain dalam menyelesaikan sengketa tersebut. Hubungan Pemerintah Pusat dengan Papua sekarang relatif lebih baik dan didasarkan otonomi khusus yang memberikan kewenangan besar kepada Pemerintah daerah Papua.
\end{abstract}

Kata kunci: Belanda, Indonesia, status quo, Irian Barat (Papua), diplomasi 


\section{INTRODUCTION}

In the Post World War Il period, decolonization or anti-colonialism was a great issue. This issue is a manifestation of the common interest of countries in Asia and Africa. Number of nations in the regions remained to be under colonialism. Even today, there are certain areas which have not yet fully gain independence. Therefore, decolonization has been struggling for centuries, even though, today, it has not yet succeeded completely. There are people movement and militia who are continuously fighting for an independence. For instance, people who live in Palestine, Tibet, Kashmir, and Cyprus have not yet had clear political status or full independence. In other words, half of its sovereignty remains to be controlled by foreign power (colonialism). Hence it is the responsibility of the international community who cares for a solidarity as universal value such as independence, liberty, equality rights, freedom, and well-being.

The decolonization issues had affected Indonesia-the Netherlands relationship. Thus, the issue of decolonization was seen indirectly as a pressure on the Netherlands colonial policy in Indonesia. The pressure was in line with the national interests of Indonesia. The issue urged execution in Round Table Conference in I949. Knowing that the Conference regulated transferred sovereignty from the Netherlands to Indonesia and Irian Barat (Papua) political status, which would negotiate one year following the RTC.

Alas, there were different perception in negotiating Irian Barat (Papua) political status between Indonesia-Netherlands. It was the main obstacle on the Irian Barat (Papua) negotiation. Netherland's political position is based on status quo policy, on the other hand, Indonesia's political position is based on nationalism in looking at the existence of Irian Barat (Papua). The difference between them led to an overlapping claim on the territory. Throughout the negotiation, the difference perception remained as an unsolved problem. Ultimately, the negotiation on the Irian Barat (Papua) dispute failed to find a solution.
The Netherlands 's status quo policy is based on an argumentation that they did not leave Papua following the Round Table Conference in I949 because they prepared communities in the region to lead its independence. Whereas, the Netherlands policy was strongly opposed by Indonesia, which argued that the entire territory of Indonesia's independence was all of the former the Netherlands colonies (Dutch East Indies) including Irian Barat (Papua). Based on this position, both of them had principal differences on Irian Barat (Papua) dispute.

\section{DECOLONIALIZATION}

Wave of decolonization issue urged the Netherlands to recognize the independence of Indonesia. On January 23, I949, in New Delhi, India, Organized Conference of Asian Countries were attended by iq countries. The Conference declared their aspirations, as follows: "I. Leaders of the Republic of Indonesia who became the Netherlands prisoner to be freed, and 2. The Netherlands troops should pull out of Yogyakarta. "(Panitia, I70,I982). An Asian solidarity supported to the Indonesian effort against the Netherlands colonialism.

Furthermore, international community supported the effort of Indonesia through the United Nations. UN Security Council on January 28, I949 stipulated that; "(I) Cessation of the Netherlands military operations, (2) the leaders of the Republic of Indonesia must be returned to Yogyakarta, (3). We should recognition over sovereignty of the United States of Indonesia." (Tim, I990). Based on this fact, it was also considered as another support of the international community for Indonesia since the Netherlands had a will to re-occupy Indonesia's territory, mainly in West and Central java.

The Conference of Asian Countries and the UN Security Council gave A political pressure on the Netherlands colonial policy in Indonesia. The pressure from the international community was seen as a part of wave of decolonization, which spread globally after World War II. The Netherlands policy upon re-colonized Indonesia after World War II was a contrast action to the spirit of decolonization, thus it received great 
challenges from the international community. The Netherlands colonial policy was criticized by the international community, meanwhile the effort of Indonesia gained support from the international community.

The international community supported the effort of Indonesia which was geared towards the convening of the Round Table Conference (RTC) in Den Haag, the Netherlands, on August 23 to 2 November 1949 (kemlu, n.d.) RTC I949 agreed upon two (2) important decisions, namely: I) The transfer of sovereignty of the Kingdom of the Netherlands to the Republic Indonesia 2) The political status of Papua is the status quo and negotiated between the Netherlands and Indonesia a year after the RTC (Siswanto, 86, 20I4).

At that time, Indonesia independence in 1945 had not been recognized by the Netherlands, consequently many countries did not recognize Indonesia as a country. Meaning that the independence of Indonesian had not been perfect yet, as in international order there are ethics, morale, and convention, or informal regulations relating to the independence of state. In this very case, the Netherlands' recognition was an utmost importance matter for Indonesia in international relations or intercommunication among nations. When decolonization issue got the attention of the international community, it was considered as a good opportunity for Indonesia to achieve a recognition from the Netherlands. Eventually, Indonesia as an independent state was recognized post RTC in 1949 and the effort of Indonesia against Colonialism could be done successfully.

However, a year following RTC in I949, it raised a problem on the relation with the political status of Irian Barat (Papua). In previous time the problems were tried to be muted in order to secure the RTC in I949, the Netherlands and Indonesia ultimately reached an agreement on the political status of Irian Barat (Papua). This agreement was delaying the completion of the Irian Barat (Papua) dispute or left the position of Papua in the status quo. This dispute would be discussed later. Quote Article 2, RTC I949 Agreement on the Papua, as follows: a. The fact that the agreement between each party's stance on the Papua yet to be achieved, so that the matter is still the subject of dispute;

b. Necessity Round Table Conference closed successfully on 2 November 1949.

c. Important factors to remember which must be considered in the solution of the problem of Papua it;

d. Limited times to identify which may be held and resolved regarding which is concerned with the problem of Papua;

e. Hard to given the task of which will be faced with the duty of promptly by the Union, and

f. Because of determination factions which concerned shall maintain the principle in order to all disputes which may later turned out, resolved by means of proper and harmonious, then the status quo residency Papua (New Guinea) remain valid determined, that within one year after the date of the transfer of sovereignty the United States of Indonesia-state position Papua problem will be resolved by means of negotiations between the Republic of Indonesia and the Kingdom of the Netherlands (Kemlu,I97I).

\section{STATUS QUO}

The Netherlands was in need of claiming a territory in Irian Barat (Papua) since it has a strategic value. It was not a surprise as the Netherlands maintained the region through an agreement in RTC 1949 implicitly. Several parties in the Netherlands argued that Irian Barat (Papua) was the last pillar that must be maintained. This view encouraged the Netherlands delegation in RTC I949 to retain Papua. The Netherlands stance towards the Irian Barat was contained in the minutes of the meeting session of Council of Ministers of the Netherlands on June 7, I949, as follows:

This is Status of New Guinea.

Minister (Opposite the ocean) van Maarseveen ask (Prime Minister) Dr. Beel about his opinion on the future status "of Papua." In the opinion of the speaker (van Maarseveen) Indonesia does not have a legal right to this territory. In addition, the possibility for the expansion will be better off under the leadership of 
the Indonesian Netherlands. Next will be important, if the Netherlands could have -a- pied a territory in the Far East in order to accommodate families in the Netherlands Environmental. Also for PKM (Dutch Shipping Company) is important al in order to have the ports in the "Papua." For the purposes of emigration, "Papua" could be considered as a partial way out to solve the population problem the Netherlands ... (Suwarno, I999)

The Netherlands fancied to be the master in Irian Barat, consequently the Netherlands did not want to leave the Papua. If we refer to the previous documents, the Netherlands had an interest to make Irian Barat as its colony. This related to the population, the Netherlands had an urge to make Irian Barat as shelters of their most population. The Netherlands is a small territory country, which has problems with land for a place to stay. In addition, the Netherlands citizens which were living in Indonesia Union required a new shelter because of a change in the political status of the Netherlands East Indies. Another consideration related to the economic aspect, the Netherlands desired to have a port in Irian Barat for ships, especially merchant vessel. Thus, the Netherlands ships can maintain the transportation path from Europe to Asia and vice versa since it has a seaport in the region. It gave economic benefits to the Netherlands. Moreover, the Netherlands can take advantage of Irian Barat as a military base. At least, three points of advantages can be achieved by the Netherlands namely economic, demography, and military.

The RTC agreement in I949 postponed the political status of Irian Barat. It was the starting point of the Papua conflict between Indonesia and the Netherlands. The status quo on Irian Barat was a part of the RTC agreement. The delegations of Indonesia and the Netherlands made correspondence to discuss Irian Barat political status. On November 2, I949 J.H. Van Maarseven, Head of the Netherlands Delegation sent a letter to Mohammad Hatta, Head of Indonesia Delegation who requested that Papua position was in status quo or not to be included in the hand over from the Netherlands to Indonesia, as follows:
With my respects to his Excellency proclaim at Noble that the Delegations to the Conference have agreed as follows.

Sentence of article 2 of the draft Charter Delivery of Sovereignty which reads: "status quo residency Irian (New-Guinea) remain valid means: "the continuing power of the Government of the Kingdom of the Netherlands on residency Irian (New-Guinea)."

"I hope as good as His Majesty proclaimed to me, whether Excellency that His Majesty may approve the above. (Natanegara, I986)

This letter was replied by Mohammad Hatta on the very same day and date. The content of the reply was Hatta approved the request. Papua remained to be under the Netherlands rule. Papua was excluded from the areas handed over from the Netherlands to Indonesia in the RTC, I949, as follows:

With respect to the majesty of our proclaim at Noble Excellency that His Majesty letter has been received; Please be informed that the Delegations of the Republic of Indonesia and the Federal Consultative Meeting for the Round Table Conference noted that the Delegations to the Conference have agreed as follows:

Sentence of article 2 of the draft charter Delivery of Sovereignty which reads; Residency status quo Papua (New-Guinea) remains in effect means:' with the continuing power of the Government of the Kingdom of the Netherlands on residency Papua (New-Guinea) (Natanegara, I986)

\section{REALISTIC DECISION}

The stance of the Indonesian delegation was to approve the request of the Netherlands delegation. Prior to replying to his letter, Hatta discussed with members of Indonesian delegation. However, Hatta as the Head of the Indonesian delegation had a strong influence in response to the letter. Hatta was responsible to the Agreement RTC article 2, I949. With the approval Maarseveen letter, Papua as an excluded territory was submitted to the Indonesia in RTC i949.

In this case, Indonesia was more concerned to achieve success of the RTC in 1949 than the Netherlands. The essence of the RTC in I949 was the transfer of sovereignty from the 
Netherlands East Indies to Indonesia. Should the RTC in I949 failed, the Netherlands would not be a problem. Notwithstanding, for Indonesia, if RTC in I949 failed, they would lose the opportunity to obtain recognition of sovereignty from the Netherlands. Recognition of sovereignty was important for Indonesia despite being declared independence in 1945 . The recognition of sovereignty was one of the characteristics of a country's existence. As previously been described, the Netherlands was also willing to organize the RTC in I949 because of the pressure from the international community. RTC held in I949 was not a sincere intention of the government of the Netherlands. Therefore, for the Netherlands, Round Table Conference (RTC) I949 may well be a successful attempt and or a flop. For the Netherlands, RTC was merely to show to the world that they were trying to hand over the sovereignty of Indonesia.

Based on the previous idea, the Indonesian delegation eventually was in realistic mind in RTC i949. The Indonesian delegation approved the status quo Netherlands over Irian Barat (Papua) although it was painful. Indonesia, as they expected that the handover of sovereignty throughout the former of the Netherlands colony was without exception. Hence, Irian Barat (Papua) should not be an exception by the Netherlands. However, if Indonesia insisted on this, a greater interest could be jeopardized. Transfer of sovereignty could fail because of a deadlock. Indonesia weighed greater interest, thus there was no other way but to accept the formula as set forth in I949. RTC Netherlands transferred sovereignty to the Indonesia Union, yet Irian Barat (Papua) remained in the status quo until there was a further result of negotiation between the Netherlands and Indonesia.

In opportunism perspective, the RTC 1949 was manipulated by the Netherlands to obtain real benefits. The Netherlands seemed set Irian Barat (Papua) as the price to be paid by Indonesia for the hand over of sovereignty. For the Netherlands the transfer of sovereignty should not pass without giving a real advantage. Moreover, the Netherlands had been accustomed to enjoying the benefits as an occupier in Indonesia. The Netherlands had a regular dredge in Indonesia produce solely for the interests, it was a pity if they left Indonesia for granted without any remuneration. Thus, the attitude of the Netherlands retaining Papua to master was to gain practical advantages. Netherlands responded on urging the international community, yet remained to get a real advantage.

In diplomacy perspective, the Netherlands did not want RTC 1949 to be seen as the Netherlands defeat of Indonesia. The Netherlands wanted to occupy parts of Indonesia, even for a while. Although Indonesia had gained support of the international community, the Netherlands did not want to merely waving white flag and restored the entire region once controlled. The Netherlands struggled and defended it from the other side. In this case, the country was not at ease to get hand over from the Netherlands East Indies as a whole to Indonesia. This submission related to the authority of the Netherlands as a force that had already occupied Indonesia for a long time. Thus, the delay delivery of Irian Barat (Papua) was a counterweight to save their prestige.

\section{PSEUDO DIPLOMACY}

The Netherlands and Indonesian tried to solve the Irian Barat (Papua) dispute through negotiation. Since 1950 negotiations on the political status of Papua had been done, however the two sides did not reach an agreement. Ultimately, bilateral diplomacy strategy as mandated by the RTC in 1949 failed in solving Irian Barat (Papua) between the two countries.

In March I950, the Netherlands delegation visited Indonesia. Their arrival was to attend the Conference of Ministers of Netherlands-Indonesian Union. One issue of this meeting was the political status of Papua. RTC mandate in 1949 stated that the political status of Papua would be negotiated one year following the Conference. During the meeting, the Netherlands and Indonesia did not reach an agreement on Irian Barat (Papua). The Netherlands delegation had an opinion that the Papua was excluded from those to be submitted to the Indonesia Union at the time of the RTC in I949, while for Indonesia, political status of Irian Barat (Papua) remained unfinished. Thus, Indonesia expected that Irian 
Barat (Papua) should be negotiated, and then handed over to Indonesia.

At first, Mohammad Hatta was optimists that Indonesia could return Irian Barat (Papua). It was based on a conversation by letter with Van Maarseveen in RTC I949, Minister for Overseas Netherlands, which guaranteed the Netherlands would hand over Irian Barat (Papua) to Indonesia. On the contrary, the various political forces in Indonesia were pessimistic that the Netherlands returned Irian Barat (Papua) to Indonesia at the end of negotiations in 1950. At that time, Netherland promises were never been fulfilled. There was no indication, the Netherlands would withdraw from Papua, they built infrastructure in the region instead.

In December 1950, there was a negotiation between the Netherlands -Indonesian. The delegations of the countries would negotiate on Irian Barat (Papua) dispute. The negotiation was held in The Hague, Netherlands. The Indonesian delegation was led by Foreign Minister, Mr. Mohammad Rum, while the Netherlands delegation was led by Mr. Van Maarseveen. At the negotiation the Indonesian delegation put forward a proposal, as follows:

I) Recognition of the existing economic and financial the Netherlands rights and concessions plus special consideration in connection with new investments and concessions and in the development and exploitation of soil and forest resources; preferential treatment for the Netherlands interests in such areas as trade, shipping and industry;

2) The Netherlands men to be eligible for employment administrative;

3) Pension's for the Netherlands officials to be guaranteed by the Indonesian Government, as in the case of the Round Table Conference Agreements;

4) Immigration of the Netherlands nationals to Irian to be permitted and due attention paid to supplying the manpower needs of West;

5) Incorporation of Papua into the Indonesian communications system but with due attention to the concessions granted to the Netherlands is earlier or mixed enterprises;

6) Guarantees for freedom of religion and assistance to the humanitarian work of religious missions by the Indonesian Government;

7) Effort to be made to operate and a fully Democratic government in Papua with a representative body to be established as soon as possible with the population possessing full autonomy and a voice in the government; (Bone, 30,1962).

This proposal was submitted by the Indonesian delegation including the position of Indonesia and accommodated the socio-economic interests of the Netherlands. Referring the Netherlands cabinet meeting on June 7, 1949, the Netherlands various interests were accommodated. In fact, the concessions granted by Indonesia in excess of the Netherlands at the cabinet met expectations. It was, among others, the Netherlands was given the opportunity to perform religious activities or activities of missionaries in Irian Barat (Papua). The Netherlands society was allowed to become administrative personnel in the region nevertheless. Thus, the Indonesian delegation tried to forge a compromise with the Netherlands.

Referring to the proposal, the Netherland should turn over their political power in Irian Barat (Papua) to Indonesia. Should the Netherlands had the economic assets and certain rights for citizens in Papua, all these rights must be regulated by the Government of Indonesia. Residents stayed must implement policies which had been formulated by the Government of Indonesia. Should the Netherlands involved in formulating policy, it could be done as far as the policy was in line with the provisions outlined by the Government of Indonesia. Thus, the Netherlands had a big concession, yet lost their political authority in Papua. Indonesia's proposal was rejected and the counter proposal was submitted by the Netherlands, as follows:

I) The sovereignty of Papua should be transferred to the Netherlands-Indonesian Union, with the stipulation that the de facto control over that territory and 
administration would remain in the Netherlands hands;

2) The negotiations should be continued under the auspices of the still extant United Nations Commission for Indonesia or any other organ could render any service to the make that possible negotiation.

3) since the future of the area had not been decided by negotiation within the year's period stipulated in article 2 of the Charter of the Transfer of Sovereignty, the Netherlands sovereignty and the status should be maintained. (Bone, 3I,I962).

The Netherlands through the proposal declared that the country did not want to lose power in Papua. By political power over the Netherlands-Indonesian Union, the Netherlands had the economic rights and social without having to request it from Indonesia. The Netherlands expected to control the administration of Papua, despite the transfer of sovereignty implemented the Netherlands-Indonesian Union. Referring to paragraph 2 of the Charter of the RTC 1949, the position of Papua will be forever in the status quo, except the Netherlands handed it over to Indonesia through negotiation. In fact, the Netherlands avoided negotiations were they invited to negotiate the substance handover of the territory to Indonesia. If the Netherlands did not submit it, Indonesia would not receive forever Papua through negotiation.

Referring to item-I proposal to the Netherlands, the transfer of sovereignty to offer the Netherlands Irian Barat (Papua) was essentially false. Papua transfer of sovereignty would not happen without the transfer of political power and administration. If the logic of the Netherlands proposal was followed, Irian Barat (Papua) would be handed over to the Indonesian-Dutch Union, not to Indonesia. Hence, submitting Irian Barat (Papua) to Indonesia principally did not exist.

The Indonesian delegation rejected the proposal the Netherlands and negotiation stalled. Bung Hatta was optimistic that the Netherlands would hand over Irian Barat yet it was proven wrong. Conversely, pessimism majority of political forces, to the Netherlands -Indonesian negotiation over Irian Barat was proven right due the Netherlands remained evasive to hand over the territory.

Furthermore, on January 26, 1954 Sunario, Minister of Foreign Affairs of Indonesia sent a letter to the Prime Minister, Sastroamidjojo, concerning the relationship between Indonesia and the Netherlands. This letter contains some matters which are summarized as follows:

I) Agreement RTC in I949 is a bridge to gain full sovereignty of Indonesia.

2) Agreements RTC should not give special status to the Netherlands.

3) Netherlands-Indonesian Union and the RTC in I949 hurt Indonesia therefore should be disbanded.

4) The relationship between Indonesia and the Netherlands plagued by two problems, namely; Netherlands-Indonesian Union matter, and the matter of Papua.

5) In the negotiations with the Netherlands should stand on principle: a.) Indonesian Union dissolved unconditionally, then after that the RTC 1949 also unconditionally disbanded and replaced with equal international relations. b). If the principles were rejected by the Netherlands Indonesian side can unilaterally dissolve the RTC i949. c). Papua will be fought at international forums inside and outside the UN.

6) Negotiations this time should be carried out by authorized officers by the Indonesian government and the Netherlands. (Yamin, I954)

Sunario looked the Netherlands -Indonesian relations had been unprofitable Indonesia. He proposed to the Prime Minister in order to set up a meeting to discuss official future of the relationship. Sunario suggested that the Netherlands-Indonesian Union and the RTC I949 revisited. Both considered it inhibits the Netherlands -Indonesian relations. Moreover, the Netherlands could not be expected in a matter of dispute resolution Irian Barat (Papua) therefore Indonesia needed a new 
strategy for resolving dispute Papua. Indonesia needed to take advantage of the support of the international community.

Sunario had an important recommendation to the Prime Minister for the development of the Netherlands -Indonesian relations. These inputs were as a reference in addressing relationship Indonesia - the Netherlands. In this regard, Indonesia suggested to lead equal international relations between the Netherlands and Indonesia. It was as commonly done globally. Thus, Sunario had made a strategic step in the right and in response to the Netherlands -Indonesian relations.

Sunario letter as Minister of Foreign Affairs and Chairman of the Ad Hoc Committee Netherlands-Indonesian Union addressed to the Prime Minister for the support the Council of Ministers. Mr. A.W. Soerjoadingrat, Secretary of the Council of Ministers, sent a letter to Sunario dated February Io, I954, No. 336I/54 concerning the Netherlands -Indonesian Union. The letter explained that the meeting of the Council of Ministers in its meeting to-33 dated February 3, I954 approved the Sunario letter dated January 26, I954. After receiving a letter from Sunario seemed that the Prime Minister discussed the letter in a cabinet meeting or the Council of Ministers and its provisions supporting the ideas Sunario Union upon Indonesia-Netherlands and the RTC I949.

Sunario, Chairman of the Ad Hoc Committee Indonesian-Dutch Union, was responsible for the development of relations between Indonesia and the Netherlands and the dispute over Irian Barat (Papua). He was trusted to formulate and give input about the future of relations between Indonesia and the Netherlands. Furthermore, he was expected to give direction to the Prime Minister to address the development of the Netherlands -Indonesian Union and the dispute over Irian barat (Papua). This needs to be done so that the presence of Indonesian-Dutch Union will not prejudice the position of Indonesia.

On February I9, I952 Netherlands unilaterally assigned Irian Barat (Papua) as an overseas territory. The Netherlands incorporate the region into the Constitution. This means that the Netherlands further strengthens its status quo policy over Irian Barat. On the other hand, Indonesia's effort for Papua gained more burden because of the consolidation of the status quo policy.

Regarding unilateral action, the Netherlands entering into the territory of Irian Barat (Papua) across the ocean deemed to violate the rules. Netherlands violated paragraph 2, I949. RTC Charter stipulated that the political status of Papua would be negotiated by the Netherlands and Indonesia. The Netherlands actions incorporating Irian Barat into its overseas territory was deemed contrary to the spirit of the Charter of I949. RTC Netherlands violated the agreement in 1949 that was witnessed by the international community. RTC I949 which was attended by the United Nations and the United States. The Netherlands unilateral action can be categorized as acts of provocation. These actions threatened the stability, security, and peace. Accordingly, the Netherlands had been showing the action of a violation of international law and did not care about the presence of the international community who witnessed the RTC I949.

Furthermore, Chargé Indonesia in The Hague sent a memorandum to the Minister of Foreign Affairs, Sunario. The memorandum dated March 24, I954, that some of the contents were summarized as follows:

I) The bilateral relationship between Indonesia and the Netherlands hampered by two things: a). Problem NetherlandsIndonesian Union, and b) Case Papua.

2) Therefore, the obstacles that need to be removed in a way, namely: a. changing the relationship on the basis of Statute Union became a regular international relations and removing harmful agreements state. B). immediately seek the return of Papua.

3) The Government of Indonesia should propose ministerial level talks coordinated by the Ministry of Foreign Affairs and implemented no later than April I954. (Soerjoadiningrat, 1954)

Chargé Indonesia in The Hague was looking at that matter Indonesian-Netherland 
Union and Papua should get immediate need of treatment by the Indonesian government. This was a constraint improvement of bilateral relations between Indonesia and the Netherlands. As far as this issue was not resolved, relations between Indonesia -Netherland will always face with the tension if one does not want to say hostility. Indonesian government needed to take concrete steps and fast to overcome it. Representatives of Indonesia and the Netherlands needed to sit together to discuss their problems thus bilateral relations between Indonesia and the Netherlands would run normally.

Indonesia decided to cancel the charter RTC Indonesia I949. The action is based on the law No. 13 of 1956 on the cancellation of the relationship between Indonesia and the Netherlands under the agreements Round Table Conference. Some important articles of the law cited as follows:

Article 2

Charter of transfer of sovereignty, the transfer of sovereignty, as well as the exchange of letters on the status quo of Papua hereby abolished and therefore is void.

\section{Section 3}

Netherlands-Indonesian Union as intended in the Statute Union hereby abolished and therefore is void.

Article 6

the relations between the Republic of Indonesia and the Kingdom of the Netherlands changed which is prevalent relationship between the countries which fully sovereign, based on international law (Undang-undang No.I3,I956).

Cancellation of RTC in I949 was also seen as a gesture of Indonesia to escape from the Netherlands's trap status quo on the dispute. Paragraph 2 of the Charter of the RTC I949 stated that the political status of Irain Barat (Papua) was in the status quo before the Netherlands handed it over to Indonesia through negotiations. Negotiation in March in Jakarta and December 1950 in Den Haag did not work towards agreement on the delivery of Papua. Until eventually, the Netherlands in I954 declared no longer willing to negotiate Irian Barat dispute with Indonesia. Thus, the effort of Papua through bilateral diplomacy was closed and needed another approach or multilateral diplomacy such as the United State Organization (UNO, 56, I954) which decision making based on majority role (the UNO Charter,I945). Moreover, Indonesia made special approach to amount countries in the five states countries in Colombo, I954, which in the conference Indonesia was struggling for Irian Barat (Sastrasmidjojo,I974,32I)

Furthermore, in 1960 as a climax of anger of Indonesia to the Netherlands regarding Irian Barat dispute was marked by the closing diplomatic relations by Sukarno. The closing of diplomatic relations as a sign that Indonesia had begun to dare the Netherlands in the military. Firstly Indonesia requested American military assistance though it was unsuccessful. Consequently, they turned to the Soviet Union (Subandrio, 2001,37). Indonesia and Soviet had similar interests that was anti-colonialism. (Abdulgani dan Gromyko, I956). After Indonesia received Soviet's assistance armaments, such as Mig-I7, anti-tank, canon, rocket, submarine, and destroyer, (Said, I984,I05). At that time, Indonesia Air Force was the most feared in South East Asia (Pohan, 2002,137) and it was better than Australia Airborne (Bhakti,I985,4). Indonesia became more confident to confront the Netherlands in the military. If it cannot be solved politically, Indonesia would be able to solve the militarily or through the war against the Netherlands. The USA saw it as a threat for stability in Asia- Pacific, hence the USA built a balance of diplomacy by approaching to President Sukarno (Gardner, I99,346) in order to negotiate the dispute under the UN and the USA. Finally it could be solved by New York Agreement 1962.

\section{JAKARTA-PAPUA RELATIONSHIP TODAY}

The statement of independence was declared at the first Papuan People's Congress in I96I. Behind this fact was nevertheless the strategy of the Netherlands in facing the Dutch-Indonesian diplomacy war. At that time, the people in Papua were in fact not ready to become independent because during the colonialism in Indonesia the Netherlands had ignored development in this region. The Netherlands solely focused on de- 
velopment in Java. The Dutch failed to convince the international community through support for an independent Papuan state because it was merely the Dutch strategy to maintain its power in the region, but unfortunately this strategy was seriously interpreted by some Papuans. A number of people believe that it was true.

The conflict between the Netherlands and Indonesia ended with the I962 New York agreement in which the agreement to hand over the sovereignty of West Irian (Papua) to Indonesia through the United Nations. The bilateral diplomacy between Indonesia and the Dutch which had been going on since the I950s had never succeeded. Indonesia changed its strategy by bringing the issue of de-colonialization Papua to the UN forum and got support to be discussed there. Based on the Cold War consideration the United States changed the stance to Papua from a neutral passive policy to become an active mediation policy.

The Independent Movement of Papua or in Indonesian is called Organisasi Papua Merdeka (OPM) was established in I965. The movement is a struggling forum for independence. The OPM continued the idea of independence which was declared at the first Papuan People's Congress in I961. Therefore, the OPM rejected the I962 New York Agreement because its content of transform of power in Papua from the Dutch to Indonesia through the United Nations. This was a contrary to the promise of the Netherlands to give independence to the people of Papua.

Hereafter, the self-determination in Papua was carried out in I969. The implementation was indeed not one man one vote but carried out through a system of representation by tribal leaders in Papua. In the referendum there was people participation represented by its chief since the Papuan people at that time were seen as left behind society thus, they were not ready to carry out direct elections system or one man one vote look like in modern people. In conducting this referendum, the majority of the Papuan people chose to join Indonesia. This implementation was witnessed by UN representatives and the United States Party. After that, the results of the referendum were brought to the UN General Assembly to be discussed and the results of the assembly that majority of countries supported the referendum. It is meaning that the international community recognized Papua as part of Indonesia.

When Indonesia entered the reformation era, freedom of speech penetrated all region in Indonesia. Therefore, the second Papuan People's Congress was held in 2000. Surprisingly the Congress rejected the I962 New York Agreement and the I969 referendum (Chauvil, 2005,9). It should not happen if the central government at that time was firm. On the contrary the Indonesian and the international community were not in a position to turn back history. Therefore, the Indonesian Government's diplomacy strategy was consistent and adhered to the I962 New York Agreement, the I969 referendum, and the decision of the United Nations General Assembly. It was the right track diplomacy. In the past, Papua's political dispute between the Netherlands and Indonesia was regulated in Article 2, the Round Table Conference in The Hague in 1949, mentioned that the political status of Papua was negotiated between the Netherlands and Indonesia. Ultimately, it met a solution by the New York Agreement in I962.

Later we have delivered a bias perspective that the Papuan dispute is seen by the ethnic and racial identity perspective. Whereas the existence of a state in modern civilization is not based on identity politics as this will easily lead to narrow fanaticism, radicalism, and in-tolerance. Countries in the era of modern civilization are open in terms of ethnicity and race. Therefore, ethnic and racial identity are irrelevant to the foundation of a country. For instance, the ethnic Malays inhabited Southeast Asia, but not necessarily the ethnic Malays established the Greater Malay state. Malay ethnicity is divided into several countries, namely Indonesia, Malaysia, Philippines, Singapore, and Brunei Darussalam. Caucasus races on the American continent are also divided into several countries, namely Canada, the United States and Mexico. Caucasus races in the southern world are also divided into Australia and New Zealand. Caucasus in Europe is also divided in many countries. The only embryo of a country 
that wants to stand based on politics of identity (religion), yet it failed and was shown by Iraq and Syria Islamic State (ISIS). The country's embryo failed to stand because it was destroyed by the United States coalition.

In discussing about Papua, the main perspective is politics and international law, but other perspectives such as anthropology can complement and help contribute to met a solution nonetheless. The root of problem in Papua is political problem. By the approach we have a relevant and comprehensive solution. One of the solutions that the problem of Papua should have been completed with special autonomy which gave great authority to the people of Papua. It is done and still going continuously, even though it needs to be revised to be even better. However special autonomy is an ideal compromise for the Government of Indonesia and the OPM.

\section{CONCLUSION}

Based on the Round Table Conference 1949 that Irian Barat (Papua) status would be negotiated one year following the Conference. There were negotiations between Indonesia and Netherland on the dispute, however it never got mutual understanding on the Irian Barat (Papua) dispute. Both of the them submitted a proposal in relations with getting the solution in the dispute, yet the countries never achieved compromise on the territorial dispute. Eventually, the countries took position to stop negotiation.

Failed diplomacy on Irian Barat was a cause of Indonesia position based on nationalism spirit on the other hand the Netherlands based on status quo. Indonesia saw the territory as a part of Indonesia, however the Netherlands saw it from different perception. The Netherlands saw the territory was not a part of Indonesia because the document of the Round Table Conference regulated that it would be negotiated one year following the conference. Indonesia delegation agreed to the idea, thus it would be a realistic stance in the conference.

In strategic perspective, the Netherland needed Irian Barat as a foothold in Far Eastern post the RTC I949. The RTC was the caused of losing its colony or Dutch East Indies (Hindia Belanda). Although the Netherlands colonialism came to an end, they needed sphere influence in Far Eastern for its national interest namely plantation, mine, over population, and shelter for Netherlander who lived in Indonesia. All of these considerations encouraged the Netherlands to take status quo policy in Irian Barat (Papua).

After the OPM was dissatisfied to the Indonesian Government, they continued the effort for independence and was gaining sympathizers and advisors abroad. Later the OPM and pro-independence society have raised the issue of political identity based on racial differences, however it did not become a reference in modern civilization thus it was difficult to accept. Therefore, the best solution in the Papuan dispute is a compromise between the Jakarta Government and the OPM. If it seems difficult to see face to face, they may ask for help from a third party as a mediator. Many conflicts can be resolved by mediators.

\section{REFERENCES}

Abdulgani, R. (1956). "Laporan Menteri Luar Negeri kepada kepada Sidang Umum DPR pada 9 Juli I956", Taufan dalam Politik Luar Negeri. Jakarta; Penerbit Endang

Abdulgani. R., Gromyko, A., Komunike Bersama Menteri Luar Negeri, II September 1956.

Bhakti, I.N. (1985) Intervensi Amerika Serikat dalam penyelesaian Politik Masalah Irian Barat, Masalah-Masalah Internasional Masa Kini. I3(I), 4 .

Bone. R. C. (1962). Jr. The Dynamic of the Western New Guinea (Papua) Problem. New York: Publisher Cornell University

Chauvel, Richard. (2005). Constructing Papuan Nationalism: History, Ethnicity, and Adaption. Washington: The East-West Center

Departmen of Public Information. (I954). Year Book of United States Organization 1954, NY: UNO

Dipna Videlia Putsanra. 20I8, November 25. Dana Otsus Papua Barat 2019 Naik Jadi Rp2,5 Triliun, Retrieved from https://tirto.id/dana-otsuspapua-barat-20ı9-naik-jadi-rp25-triliun-darI

Departemen Luar Negeri. (197I). Dua Puluh Lima Tahun Departemen Luar Negeri 1945-I970. 
Jakarta: Penerbit Direktorat Penelitian dan Pengembangan

Gardner, P. (I999). 50 tahun Amerika Serikat-Indonesia, trans. Pericles Katoppo. Jakarta: P.T. Sinar Harapan Press.

Kemlu, (n.d) Momen Penting dalam sejarah Diplomasi Indonesia, retrieved from http;// www.kemlu.go.id,

Soerjoadingrat, A.W. (1954). Surat-surat Sekretaris Dewan Menteri kepada Menteri Luar Negeri Sunario, tanggal Io February 1954

Subandrio, (200I). Meluruskan Sejarah Perjuangan Irian Barat. Jakarta: Yayasan Kepada Bangsaku

Suwarno, B. (1999). Hubungan Indonesia-Belanda Peiode 1945-1950. Jakarta: Penerbit Printing Upakara

Said, T. (1984). Indonesia dalam Politik Global Amerika Serikat. Medan: Penerbit Waspada

Sastramidjojo, A. (I974). Tonggak-Tonggak di Perjalananku, Jakarta: PT. Kinta

Siswanto. (2016). Diplomasi Belanda dan Indonesia dalam Sengketa Irian Barat, I949-I950: Sebuah Kajian Sejarah. Jurnal penelitian Politik 2 (I), 65-72, retrieved from http:// ejournal.politik.lipi.go.id/index.php/jpp/ article/view/402/229
Pohan, D. (2002). Kembali ke Jatidiri Bangsa Indonesia. Jakarta: Milineum Publisher

Undang-undang No.I3 tahun 1956 tentang Pembatalan Hubungan Indonesia-Belanda Berdasarkan Perdjnjian Konperensi Medja Bundar

Natanegara, S. (1986). Api Perjuangan Irian Barat. Jakarta: Yayasan Badan Kontak Keluarga Besar Pejuang Irian Barat

Panitia Peringatan 75 tahun Kasmsn. (1982). Hidup itu Berjuang: kasman Singodimejo 75 tahun. Jakarta: Penerbit Bulan Bintang

United Nations Organization Charter, (1945). NY: $\mathrm{UNO}$

Yamin, M. (I954)."Script FIN-EC", Commissioner General of the Republic of Indonesia in The Hague 